\title{
Bat necrophagy by a whip-spider (Arachnida, Amblypygi, Phrynidae) in a cave in the eastern Brazilian Amazon
}

\author{
Xavier PROUS ${ }^{1 *}$, Thadeu PIETROBON ${ }^{1}$, Mariane S. RIBEIRO ${ }^{1}$, Robson de A. ZAMPAULO ${ }^{1}$ \\ 1 Vale - Environmental Licensing and Speleology. Av. Dr. Marco Paulo Simon Jardim, 3580, Nova Lima - MG, Brasil. 34006-270 \\ *Corresponding author: xavier.prous@vale.com
}

\begin{abstract}
Amblypygids are among the main predators in the ferriferous caves in Carajás National Forest, state of Pará (Amazon region of Brazil). One of the most common amblypygid species in this region is Heterophrynus longicornis (Butler 1873), and its most frequent prey are crickets of the family Phalangopsidae, which are abundant in the caves of Pará. Because they are primarily predators, necrophagy by amblypygids is not frequent in nature, and there are only two literature records of necrophagy of bats by Amblypygi. On December $11^{\text {th }}, 2013$, we observed an individual H. longicornis eating a bat carcass in a Pará ferriferous cave. The amblypygid exhibited considerable interest in the bat's carcass, and it did not interrupt its meal even when lamps or a camera's flash were pointed in its direction. The availability of nutrients in the carcass must promote this opportunistic behavior in caves, especially considering the habitual scarcity of trophic resources in underground environments when compared to epigean environments.
\end{abstract}

KEYWORDS: Heterophrynus longicornis, Chiroptera, cave, feeding behavior

\section{Necrofagia de morcego por um amblipígio (Arachnida, Amblypygi, Phrynidae) em uma caverna no leste da Amazônia brasileira}

\section{RESUMO}

Amblipígios são considerados um dos principais predadores em cavernas de litologia ferrífera localizadas na Floresta Nacional de Carajás no estado do Pará (região da Amazônia brasileira). Uma das espécies de amblipígios mais comuns nesta região é Heterophrynus longicornis (Butler 1873), e uma das presas mais frequentes são grilos da família Phalangopsidae, abundantes nas cavernas do Pará. Por serem predadores, a necrofagia em amblipígeos foi pouco observada na natureza, sendo que existem dois registros na literatura sobre necrofagia de morcegos por amblipígios. Em 11 de dezembro de 2013, observamos um $H$. longicornis se alimentando da carcaça de um morcego em uma caverna de litologia ferrífera da Floresta Nacional de Carajás. Aparentemente, havia um interesse considerável pela carcaça do morcego por parte do amblipígio, uma vez que o indivíduo não interrompeu sua alimentação, mesmo quando iluminado por lanternas e o flash da câmera. A abundância de nutrientes na carcaça deve favorecer este comportamento oportunístico em cavernas, especialmente quando se considera a habitual escassez de recursos tróficos destes ambientes subterrâneos, quando comparados a ambientes epígeos.

PALAVRAS-CHAVE: Heterophrynus longicornis, Chiroptera, caverna, comportamento alimentar 
Amblypygi is an arachnid order with approximately 200 described species (Giupponi and Miranda 2016; Miranda et al. 2016). The order is widely distributed, but it is more abundant in tropical regions (Weygoldt 2000). Amblypygids are usually found in caves and are frequently one of the main predators in cave food webs (Ferreira and Martins 1999; Redell 2012; Chapin 2015; Chapin and Hebets 2016).

Records of amblypygid diets and feeding behavior are rare, presumably because of their nocturnal and variable feeding habits (Ladle and Velander 2003). Arthropods are the main prey of amblypygids, even though there are records of them eating vertebrates, such as lizards, amphibians, and even birds (Reagan 1996; Kok 1998; Weygoldt 2000; Ladle and Velander 2003; Dias and Machado 2006; Owen and Cokendolpher 2006; Wizen and Aznar 2016). Even though there are records of amblypygids eating carcasses in the laboratory (Weygoldt $1995,2000)$, necrophagy is rarely observed in nature. Owen and Cokendolpher (2006) observed an amblypygid eating a hummingbird, but were unable to determine whether it was a predation event or necrophagy. There are, nonetheless, two records of bat necrophagy by amblypygids (Armas and Collado 1999; Rivera et al. 2009). The first record presents few details of this behavior, observed on Phrynus longipes (Pocock 1893) (Phrynidae) in a Dominican Republic cave (Armas and Collado 1999). The second record documents a case of necrophagy by the species Paraphrynus robustus (Franganillo 1930) (Phrynidae), feeding on Phyllonycteris poeyi (Gundlach 1860) (Phyllostomidae) bats in a Cuban cave (Rivera et al. 2009).

In this note, we report the first observation of bat necrophagy by amblypygids in caves in the Amazonian region. Heterophrynus longicornis (Butler 1873) (Phrynidae) is common in Amazonian caves, especially the ferriferous caves located in Carajás National Forest in the Brazilian state of Pará. Our observations were made in cave S11-0007 $\left(6.2720^{\circ} \mathrm{S}, 50.1430^{\circ} \mathrm{W}\right)$, also known as "Labirinto de Máfica" cave (Crescencio and Carmo 2013), located in Canaã dos Carajás in the southeastern part of the state of Pará (Figure 1). The cave is embedded in a ferriferous formation, it has three small entrances and maze conduits with an average height of 1.0 meter, and is about 1,500 meters long overall. A total of 110 species have already been observed in this cave, including many species of arachnids (more than 30 specimens of H. longicornis, identified using Weygoldt 2002), crickets, isopods, and other arthropods (Carste 2010). The main prey of H. longicornis in Carajás caves are Phalangopsis (Serville 1831) crickets (Phalangopsidae), which are also abundant in this cave (Figure 2a).

On December $11^{\text {th }}, 2013$, we observed an individual $H$. longicornis feeding on a bat carcass at $6 \mathrm{pm}$, about 40 meters

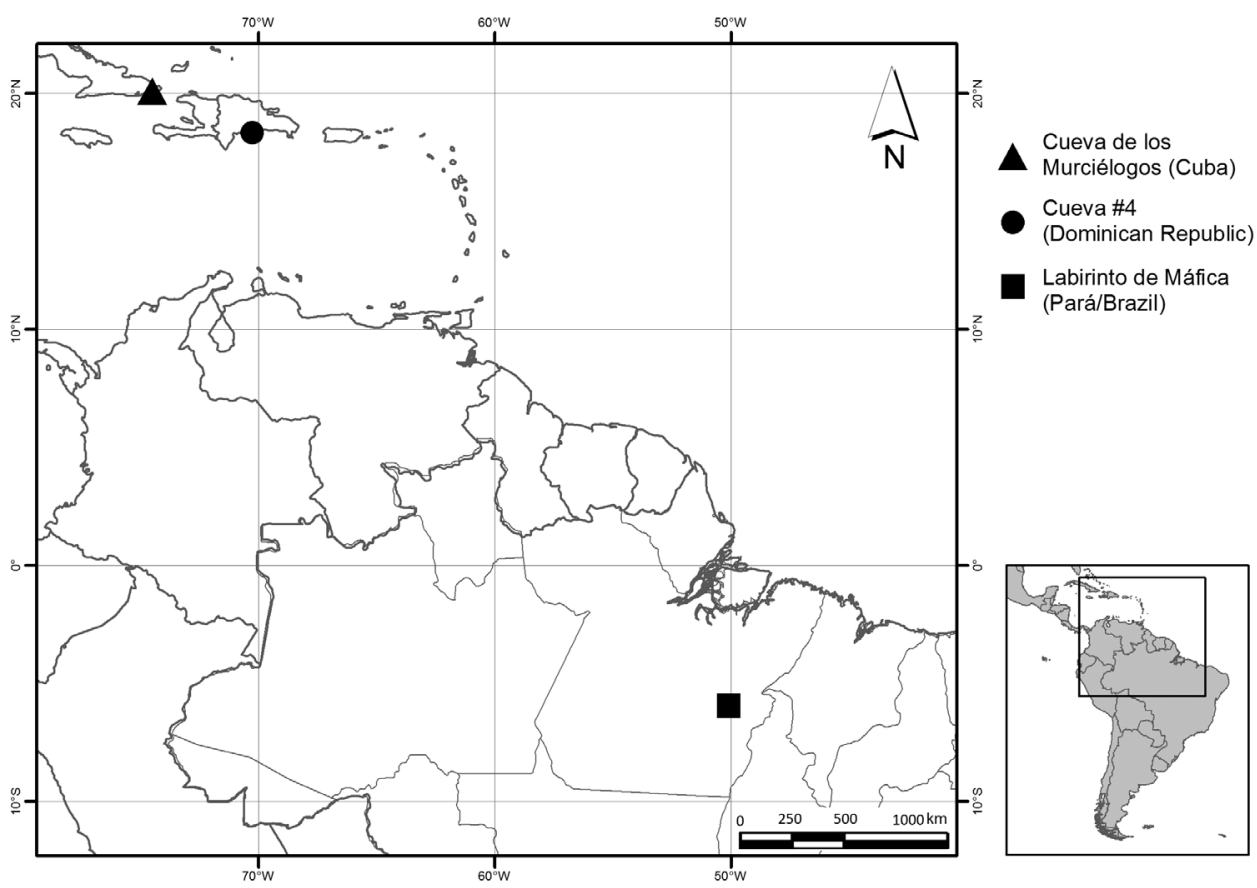

Figure 1. Location of new record of bat necrophagy by Amblypygi in the "Labirinto de Máfica" cave, Canaã dos Carajás, Pará, Brazil, indicated on the map by a solid square. The solid circle indicates the record from a Dominican Republic cave (Armas and Collado 1999), and the solid triangle indicates the record from a Cuban cave (Rivera et al. 2009) 

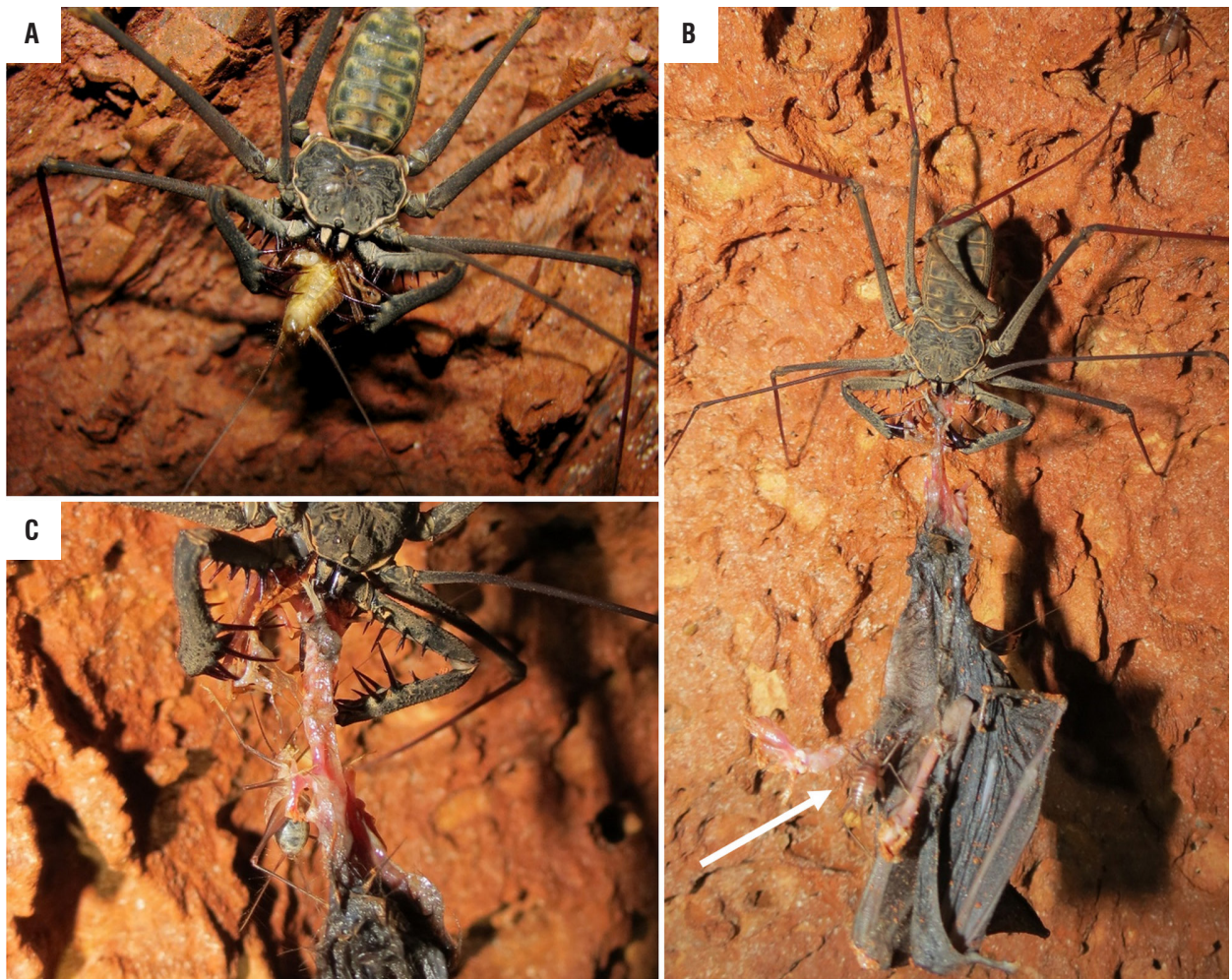

Figure 2. a-c. a) Heterophrynus longicornis eating a Phalangopsis sp. cricket, one of its most common prey items, in the Carajás caves (Pará state, Brazil). b) $H$. Iongicornis lifting the bat's carcass almost exclusively by its chelicerae, and a Phalagopsis sp. cricket feeding on the wing musculature of the bat (white arrow). c) Detail of the amblypygid ignoring the Phalangopsis sp. cricket near its pedipalps. This figure is in color in the electronic version.

in from one of the cave's entrances. It was not possible to identify the bat's species due to the condition of the carcass at the time. In this cave, there are five bat species known (Carollia perspicillata Linnaeus 1758, Diphylla ecaudata Spix 1823, Glossophaginae sp. Bonaparte 1845, Lonchorbina aurita Tomes 1863, and Desmodus rotundus Geoffroy 1810), with average weights varying from 10 to 40 grams. The $H$. longicornis individual was found on the cave wall approximately 80 centimeters above the ground, using its chelicerae and pedipalps to lift the bat (Figure 2b). When the observers approached the amblypygid, it moved to the top of the wall, almost reaching the ceiling, but without releasing the bat, which it held strongly in its chelicerae. Interestingly, the pedipalps did not seem to do significant strength to lift the bat. Neither the observers' presence, the lamps, nor the camera's flash disturbed the amblypygid enough to make it stop eating the bat.

It seemed the amblypygid was feeding on the leg musculature of the bat. Parts of the wings were already fleshless, exposing the humerus and scapula. It is not possible to say, however, whether the amblypygid also ate those parts, considering that a Phalangopsis sp. cricket was found eating the bat as well, specifically in the forearm area (Figure 2b).
Rivera et al. (2009) speculated that part of the bat's skin they observed had been removed by cockroaches and other detritivores, and this may also have occurred in the scenario we observed. Furthermore, considering the crickets' greater mobility and abundance, they would most likely be the first to reach this kind of resource when it becomes available.

The amblypygid displayed great interest in the resource, and ignored not only the cricket presence on the bat, but also the cricket walking over the amblypygid itself and near its pedipalp (Figure 2c). Rivera et al. (2009) suggested that the effort necessary for an amblypygid to lift a bat to the ceiling must be great, but worth it due to the amount of nutrients in the carcass.

Food scarcity in caves stimulates generalized feeding behavior in cave species, encouraging them to consume any trophic resources available in the environment (Hüppop 2000). Chapin (2015), for example, observed significant variation in individual behavior in an underground Phrynus longipes (Pocock 1894) population compared to a surface population. Despite the lack of records, in light of their behavioral phenotypic plasticity, it is possible that bat necrophagy by amblypygids is not rare when both are abundant in Amazonian caves. 


\section{ACKNOWLEDGEMENTS}

We thank Allan Calux and Ramon Araújo for preparing the maps, two anonymous referees for their comments on the manuscript, and Vale's Environmental Licensing and Speleology Department for its encouragement of our fieldwork. We also thank Valdir Ribeiro Lima and Antonio Ribeiro Lima for their support and guidance in the field. This work was supported by Vale S.A.

\section{REFERENCES}

Armas, L.F. de; Collado, D.A. 1999. Mitos y realidades sobre el guabá. Hoy (Santo Domingo), República Dominicana, 18 de marzo, p.22B.

Carste Consultores Associados. 2010. Espeleologia do projeto S11D, Serra Sul, Regiāo de Carajás, PA. p.224. Technical report. (http:// licenciamento.ibama.gov.br/Mineracao/Projeto $\% 20$ Ferro $\% 20$ Carajas\%20S11D/Espeleologia/Relevancia/Espeleologia\%20 S11D_Final_PRINT.pdf). Accessed on 13/03/2017.

Chapin, K.J. 2015. Cave-epigean behavioral variation of the amblypygid Phrynus longipes (Arachnida: Amblypygi) evidenced by activity, vigilance, and aggression. Journal of Arachnology, 43: 214-219.

Chapin, K.J.; Hebets; E.A. 2016. The behavioral ecology of amblypygids. Journal of Arachnology, 44: 1-14.

Crescencio, G.G.; Carmo, P.L. 2013. Cavernas, mineração e comunidades da Amazônia: a caverna Labirinto de Máfica e o caso da Vila na Racha Placa em Canaã dos Carajás/ $P A$. Anais do 320 Congresso Brasileiro de Espeleologia, Campinas, SP, Brasil, p.167-173. (http://www.cavernas.org.br/ anais32cbe/32cbe_167-173.pdf)

Dias, S.C.; Machado; G. 2006. Microhabitat use by the whip spider Heterophrynus longicornis (Amblypygi, Phrynidae) in Central Amazon. Journal of Arachnology, 34: 540-544.

Ferreira, R.L.; Martins; R.P. 1999. Trophic structure and natural history of bat guano invertebrate communities, with special reference to Brazilian caves. Tropical Zoology, 12: 231-252.

Giupponi, A.P.deL. Duas novas sinonímias no gênero Heterophrynus Pocock, 1894 (Amblypygi, Phrynidae). Revista Ibérica de Aracnología, 6: 173-175.

Giupponi, A.P.de L.; de Miranda, G.S. 2016. Eight new species of Charinus Simon, 1892 (Arachnida: Amblypygi: Charinidae) endemic for the Brazilian Amazon, with notes on their conservational status. PLoS ONE 11(2): e0148277.
Hüppop, K. 2012. Adaptation to low food. In: Culver, D.C.; White, W.B. (Ed). Encyclopedia of Caves. 2nd ed. Elsevier Academic Press, San Diego, CA, USA, p.1-8.

Kok, P. 1998. Anolis nitens chrysolepis (goldenscale anole) predation. Herpetological Review, 29: 41.

Ladle, R.J.; Velander, K. 2003. Fishing behavior in a giant amblypygid. Journal of Arachnology, 31: 154-156.

Miranda, G.S.; Milleri-Pinto, M.; Gonçalves-Souza, T.; Giupponi, A.P.L.; Scharff, N. 2016. A new species of Charinus Simon 1892 from Brazil, with notes on behavior (Amblypygi, Charinidae). ZooKeys 621: 15-36. doi: 10.3897/zookeys.621.9980

Owen, J.L.; Cokendolpher, J.C. 2006. Tailless whipscorpion (Phrynus longipes) feeds on Antillean Crested Hummingbird (Orthorhyncus cristatus). The Wilson Journal of Ornithology, 118: 422-423.

Reagan, D.P. 1996. Anoline lizards. In Reagan, D.P.; Waide, R.B (Ed). The food web of a tropical rain forest. University of Chicago Press, Chicago. p.321-345.

Reddell, J.R. 2012. Spiders and related groups. In: Culver, D.C.; White, W.B. (Ed). Encyclopedia of Caves. 2nd ed. Elsevier Academic Press, San Diego, p.786-796.

Rivera, L.G.; Espín, R.M.; Armas, L.F.; Hernández, N.H. 2009. Necrofagia en Amblypygi (Arachnida: Pedipalpi). Boletín de la Sociedad Entomológica Aragonesa, 45: 505-507.

Weygoldt, P. 2000. Amblypygids (Chelicerata: Amblypygi): Their Biology, Morphology and Systematics. Apollo Books, Stenstrup, Denmark, 163p

Weygoldt, P. 2002. Amblypygi. In: Adis, J. (Ed.), Amazonian Arachnida and Myriapoda: Identification Keys to All Classes, Orders, Families, Some Genera and Lists of Known Terrestrial Species. Pensoft Publishers, Sofia, p.293-302.

Weygoldt, P. 1995. A whip spider that ate rolled oats, with observations on prey-capture behavior in whip spiders. Newsletter of the British Arachnological Society, 74: 6-8

Wizen, G.; Aznar, J. 2016. Pristimantis achatinus (Cachabi Robber Frog). Predation. Herpetological Review, 47: 440-441.

Received: 28/03/2017

Accepted: 28/06/2017 